\title{
EFFECT OF VARIOUS TYPES OF REMOVABLE APPLIANCES AND DENTAL IMPLANTS ON THE ORAL MICROBIOCENOSIS DURING ORTHOPEDIC TREATMENT
}

Tlustenko VP, Bairikov IM, Trunin DA, Komlev SS $\bowtie$, Zhestkov AV, Lyamin AV

Samara State Medical University, Samara, Russia

The problem of complications arising after dental implantation is still relevant. The aim of the work was to investigate the effect of various types of removable appliances and dental implants on the oral microbiocenosis during orthopedic treatment of 64 people: 12 patients of the first index group, 40 patients of the second index group and 12 people of the control group. 6 months after the implants were installed, as a result of a microbiological study of the oral cavity, the differences were found in the qualitative composition of the microflora of the mucous membrane around the neck of the dental implant. In the first index group representatives of normal microflora prevailed. In 100\% of cases Streptococcus vestibularis was isolated, from more than half patients S. oralis, S. mitis, Rothia mucilaginosa were isolated, S. gordonii was isolated from one patient. In the second index group, a significant diversity of microbial species was observed, including enterobacteria, which were isolated from $22.5 \%$ of the examined patients. In the control group, in addition to representatives of the normal microflora of the oral mucosa S. vestibularis (75.5\%), S. oralis (50.0\%), Neisseria subflava (66.7\%) and Haemophylus parainfluenzae (50.0\%) were found. From all patients of the control groups S. gordonii was isolated, as well as the other potentially pathogenic streptococci species, S. anginosus and S. constellatus by $66.7 \%$. The type of removable appliances and dental implants used affects the microflora composition of the oral cavity, and, consequently, the further prognosis and the risk of complications. Collapsible dental implant supported removable prosthetic appliances with a metal frame and fixing elements, telescopic crowns and clasps less than other types of prosthetic appliances change the qualitative composition of the microflora of the oral mucosa around the neck of the dental implant.

Keywords: microbiocenosis, implantation, collapsible dental implant, removable prosthetic appliances

Author contribution: Tlustenko VP, Bairikov IM, Trunin DA, Komlev SS - concept and research design, surgical and orthopedic treatment of patients; Bairikov IM, Komlev SS, Zhestkov AV, Lyamin AV — collection and processing of material, microbiological investigation of clinical material, statistical processing of results.

Compliance with ethical standards: the study was approved by the Ethics Committee of Samara State Medical University (protocol № 2018/197). All patients signed a voluntary informed consent for the dental implantation operation, orthopedic treatment and participation in the study.

$\triangle$ Correspondence should be addressed: Sergey S. Komlev

Chapayevskaya 89, Samara, 443099; stomat.ks@mail.ru

Received: 27.01.2019 Accepted: 08.04.2019 Published online: 18.04.2019

DOI: $10.24075 /$ brsmu.2019.029

\section{ВЛИЯНИЕ РАЗЛИЧНЫХ ВИДОВ СЪЕМНЫХ КОНСТРУКЦИЙ И ДЕНТАЛЬНЫХ ИМПЛАНТАТОВ НА МИКРОБИОЦЕНОЗ ПОЛОСТИ РТА ПРИ ОРТОПЕДИЧЕСКОМ ЛЕЧЕНИИ}

\author{
В. П. Тлустенко, И. М. Байриков, Д. А. Трунин, С. С. Комлев $凶$, А. В. Жестков, А. В. Лямин
}

Самарский государственный медицинский университет, Самара, Россия

Проблема осложнений, возникающих после проведения дентальной имплантации, остается актуальной. Целью работы было исследовать влияние различных видов съемных конструкций и дентальных имплантатов на микробиоценоз полости рта при ортопедическом лечении 64 человек: 12 пациентов 1-й основной группы, 40 пациентов 2-й основной группы и 12 человек группы контроля. Через 6 месяцев после установки имплантатов в результате микробиологического исследования полости рта были выявлены различия в качественном составе микрофлоры слизистой оболочки вокруг шейки дентального имплантата. В основной группе 1 преобладали представители нормальной микрофлоры. В 100\% случаев выделен Streptococcus vestibularis, более чем у половины пациентов выделены S. oralis, S. mitis, Rothia mucilaginosa, S. gordonii выделен у одного пациента. В основной группе 2 отмечено значительное разнообразие видов микроорганизмов, включая энтеробактерии, которые были выделены у 22,5\% обследованных. В контрольной группе помимо представителей нормальной микрофлоры слизистой оболочки полости рта обнаружены S. vestibularis (75,5\%), S. oralis (50,0\%), Neisseria subflava (66,7\%) и Haemophylus parainfluenzae (50,0\%). У всех пациентов контрольной группы были выделены S. gordonii, а также другие виды потенциально патогенных стрептококков - S. anginosus и S. constellatus по 66,7\%. Вид используемых съемных конструкций и дентальных имплантатов влияет на состав микрослоры полости рта, а, следовательно, на дальнейший прогноз и риск развития осложнений. Съемные ортопедические конструкции с металлическим каркасом и фиксирующими элементами, телескопическими коронками и замковыми креплениями с опорой на разборные дентальные имплантаты менее других видов конструкций изменяют качественный состав микрофлоры слизистой оболочки полости рта вокруг шейки дентального имплантата.

Ключевые слова: микробиоценоз, дентальная имплантация, разборный дентальный имплантат, съемные ортопедические конструкции

Информация о вкладе авторов: В. П. Тлустенко, И. М. Байриков, Д. А. Трунин, С. С. Комлев - разработка концепции и дизайна исследования, хирургическое и ортопедическое лечение пациентов; И. М. Байриков, С. С. Комлев, А. В. Жестков, А. В. Лямин - сбор и обработка материала, микробиологическое исследование клинического материала, статистическая обработка.

Соблюдение этических стандартов: исследование одобрено этическим комитетом Самарского государственного медицинского университета (протокол № 2018/197). Все пациенты подписали информированное согласие на проведение операции дентальной имплантации и ортопедическое лечение и участие в исследовании.

$\bowtie$ Для корреспонденции: Сергей Сергеевич Комлев ул. Чапаевская, д. 89, г. Самара, 443099; stomat.ks@mail.ru

Статья получена: 27.01.2019 Статья принята к печати: 08.04.2019 Опубликована онлайн: 18.04.2019

DOI: $10.24075 /$ vrgmu.2019.029

Despite significant achievements in solving technical issues, the problem of complications after the dental implants installation is still relevant in modern dental implantology [1]. The most common are mucositis and periimplantitis, in the development of which microorganisms take an active part, both normally presented in the oral cavity and colonizing surfaces of materials of which dental implants and removable appliances are constructed [2-5].

In literature, the ability of microorganisms to adhere to the surface of dental implant abutments and removable prosthetic 
appliances is described. As test microorganisms, bacteria are most often evaluated, which are not fundamental in terms of the development of pathological processes associated with the use of dental implants [6-8].

Additional difficulties in evaluating oral microbiota when using removable prosthetic appliances and dental implants arise from the imperfection of the applied laboratory diagnostics methods and improperly constructed research design. Researchers are most commonly limited to a general assessment of anaerobic and/or aerobic microflora without regard to its species diversity; to using nothing but methods based on the detection of DNA of microorganisms, representatives of pathogenic complexes; in some cases, methods which are obviously unacceptable for purposes of assessment of oral cavity microflora are used, for example, test systems developed to evaluate microflora of other loci of the human body [9-11].

This approach can lead to contradictory results when assessing the qualitative and quantitative composition of oral microflora, and also make it difficult to evaluate the role of microflora representatives in the development of complications associated with the dental implants installation; qualitative and quantitative composition of microflora when comparing the influence of similar prosthetic appliances constructed of various materials. Moreover, pathogenicity factors and complex architectonics of the interaction of various types of microorganisms during the colonization of the surfaces of dental implants and removable prosthetic appliances by normal, pathogenic and transient microflora are not taken into account.

The aim of the work was to investigate the effect of various types of dental implants on the oral cavity microbiocenosis.

\section{METHODS}

Microbiological investigation was performed in 64 patients with various types of dental implants (22 men and 42 women aged 45-65): 12 patients of the first index group, 40 patients of the second index group, the control group was formed of 12 people. Criteria for inclusion in the study: presence of unilateral and bilateral free-end edentulous spaces. Exclusion criteria: presence of diseases of the circulatory system; presence of cancer.

The collection and transportation of biological material was carried out in accordance with the requirements of the 4.2.2039-05 "Method of collecting and transporting of biomaterials in microbiological laboratories» guidelines. Samples of material for microbiological investigation were collected from the mucous membrane of the oral cavity around the neck of a dental implant with sterile cotton swabs, which were placed into transport media for aerobic and anaerobic microorganisms immediately after collection. The material was transported to the laboratory in 2 hours under isothermal conditions at $22-24^{\circ} \mathrm{C}$.

In the laboratory, the material was inoculated on the solid media: blood agar, HiCrome universal differentiation medium (HiMedia; India), agar for anaerobic microorganisms (HiMedia; India), selective media for isolation of staphylococci - mannitol salt agar (HiMedia; India), for isolation of fungi - Sabouraud agar (HiMedia; India), for enterobacteria — Endo agar (HiMedia; India), for non-fermenting gram-negative bacteria - cetrimide agar (HiMedia; India). Cultivation was performed under aerobic and anaerobic conditions using the anaerobic culture jars and the BD GasPak ${ }^{\mathrm{TM}}$ EZ Container Systems commercial gas generating pouches (BD; USA) for $48-72$ hours at $35-37^{\circ} \mathrm{C}$.

The microorganisms isolated were identified using MALDIToF mass-spectrometry with the Microflex LT unit (MALDI Biotyper 3.1, Bruker Daltonik GmbH; Germany).
The material was collected 6 months after the orthopedic treatment of patients. The qualitative composition of the isolated microflora was assessed taking into account the grouping of microorganisms depending on their potential pathogenetic effects on the oral mucosa and bone tissue.

In total, 328 strains of microorganisms of 26 genera were isolated and identified.

Evaluation of the microflora composition of the oral mucosa around the neck of the dental implant was performed in 64 patients. Depending on the design of the dental implant and the removable prosthetic appliance, all patients who underwent a microbiological study were divided into three groups.

1. The 1st subgroup of the index group (index group 1) included 12 patients for whom the collapsible dental implants supported removable prosthetic appliances with a metal frame and fixing elements, using telescopic crowns and clasps were constructed (patent of Russian Federation № 2593349). After the operation of implantation and irreversible bone resorption with the proposed implant design, it became possible to detach the intermediate part from the osseointegrated apical part and use the apical part to fix the abutment, the removable prosthetic appliance.

2. The 2 nd subgroup of the index group (index group 2) included 40 patients, for whom the commercial dental implants supported removable prosthetic appliances were constructed, the fixing clasps were located in the metal frame of the removable prosthesis.

3. The control group included 12 patients, for whom the commercial dental implants supported removable prosthetic appliances of acrylic plastics were constructed, the fixing elements were located in the basis of a removable prosthetic appliance.

\section{RESULTS}

All microorganisms colonizing the mucous membranes of the oral cavity may have a certain pathogenic potential, but in some of them it is more pronounced, in others it seldom occurs. Thus, we conditionally divided the isolated microorganisms into representatives of the normal biota of the oral mucosa (Streptococcus salivarius, Streptococcus vestibularis, Streptococcus parasanguinis, Streptococcus oralis, Streptococcus sanguinis, Streptococcus mitis, Rothia dentocariosa, Rothia mucilaginosa, Neisseria macacae, Neisseria subflava, Neisseria flavescens, Haemophilus parainfluenzae, Lactobacillus salivarius, Gemella haemolysans), microflora that participates in pathogenic processes at various levels (Streptococcus anginosus, Streptococcus gordonii, Streptococcus constellatus), microflora, less characteristic for the oral mucosa, but usually not involved in pathological processes (Acinetobacter junii, Staphylococcus capitis, Staphylococcus epidermidis, Staphylococcus warnerii, Streptococcus pneumoniae), microflora with high pathogenic potential that is not typical for the oral cavity (Enterobacter cloacae, Citrobacter freundii, Escherichia coli). A separate group consisted of the Candida genus fungi.

During the qualitative composition analysis of the microflora of the oral mucosa around the dental implant in patients of the studied groups the data were obtained presented in the following table.

The analysis of the obtained data revealed the following features of the qualitative composition of microorganisms in the microbiocenosis structure of the oral mucosa around the dental implant neck.

A distinctive feature of the microflora of the 1st index group patients was the predominance of normal flora in a 
significant part of the patients examined. In $100 \%$ of cases Streptococcus vestibularis was isolated, from more than half patients Streptococcus oralis, Streptococcus mitis, Rothia mucilaginosa were isolated. Enterobacteria and Candida fungi were not isolated in this group of patients. However, a rather frequent isolation of saprophytic microflora, uncharacteristic for the oral mucosa, should be noted, which was found in half of the patients.

The 2nd index group was characterized by a significant variety of microorganisms. In patients, the dominant group of microorganisms had not been revealed. Nevertheless, the microflora was more often represented by normal microorganisms characteristic for the oral mucosa, among which Streptococcus vestibularis prevailed. From one-third of the patients potentially pathogenic microorganisms were isolated. But, in our opinion, the fact that from 9 patients enterobacteria, which are uncharacteristic for this locus and possess significant pathogenic potential, were isolated, had the greatest value in this group, both for production of proteolytic enzymes, and for direct participation in the development of infectious complications of various localization.

Streptococcus vestibularis and Streptococcus oralis, as well as Neisseria subflava and Haemophilus parainfluenzae as representatives of the normal oral microflora prevailed in the control group. The other representatives of the normal flora were isolated from less than $50 \%$ of the examined patients in the control group. A distinctive feature of the microflora in patients of the control group was the wide distribution of microorganisms that play an important role as triggers in the pathogenic microflora colonization. Streptococcus gordonii was isolated from all patients of the control group, having an increased adhesive ability, which is realized by microorganisms with pronounced pathogenic potential. Besides, Streptococcus anginosus and Streptococcus constellatus were isolated from more than a half of the control group patients. Only in the control group the Candida genus fungi were isolated, represented by the one single Candida albicans species (it was isolated from one third of the patients).

Thus, in patients of the 1st index group, the implantological treatment carried out using collapsible dental implants and the orthopedic treatment demonstrate the smallest change in the qualitative composition of the microflora of the oral mucosa around the neck of the dental implant. It should be noted that no representatives of the "red" paradontopathogenic complex were isolated from patients of all groups.

In addition to the qualitative composition, the frequency of isolation of microorganisms by groups and genera was analyzed taking into account their potential participation in the pathological process. Due to the significant influence of certain types of streptococci on pathogenic processes, it was decided to divide them into two groups: "having potential pathogenic significance" and "normal flora representatives".

Data on the frequency of isolation of representatives of different groups of microorganisms from patients are presented in Fig 1.

The following microflora features were identified. In the 1st index group, when analyzing the frequency of isolation of various groups of microorganisms representatives, the significant

Table. Qualitative composition of the microflora of the mucous membrane around the dental implant (number of strains in absolute numbers and proportion of strains of the total number of microorganisms isolated from the group)

\begin{tabular}{|c|c|c|c|}
\hline Microorganism species & Control group & Index group 1 & Index group 2 \\
\hline Streptococcus salivarius & $2(16.7 \%)$ & $2(16.7 \%)$ & $12(30.0 \%)$ \\
\hline Streptococcus vestibularis & $9(75.0 \%)$ & 12 (100\%) & $24(60.0 \%)$ \\
\hline Streptococcus parasanguinis & 0 & $2(16.7 \%)$ & $8(20.0 \%)$ \\
\hline Streptococcus oralis & $6(50.0 \%)$ & $10(83.3 \%)$ & $12(30.0 \%)$ \\
\hline Streptococcus sanguinis & $3(25.0 \%)$ & 0 & $15(37.5 \%)$ \\
\hline Streptococcus mitis & $4(33.3 \%)$ & $6(50.0 \%)$ & $12(30.0 \%)$ \\
\hline Streptococcus anginosus & $8(66.7 \%)$ & 0 & 0 \\
\hline Streptococcus gordonii & $12(100 \%)$ & $1(8.3 \%)$ & $9(22.5 \%)$ \\
\hline Streptococcus constellatus & $8(66.7 \%)$ & 0 & 0 \\
\hline Streptococcus pneumoniae & $3(25.0 \%)$ & $4(33.3 \%)$ & $4(10.0 \%)$ \\
\hline Rothia dentocariosa & $3(25.0 \%)$ & $2(16.7 \%)$ & $3(7.5 \%)$ \\
\hline Rothia mucilaginosa & 0 & $8(66.7 \%)$ & $18(45.0 \%)$ \\
\hline Neisseria macacae & $3(25.0 \%)$ & 0 & $3(7.5 \%)$ \\
\hline Neisseria subflava & $8(66.7 \%)$ & $2(16.7 \%)$ & $18(45.0 \%)$ \\
\hline Neisseria flavescens & 0 & $2(16.7 \%)$ & $4(10.0 \%)$ \\
\hline Haemophilus parainfluenzae & $6(50.0 \%)$ & $1(8.3 \%)$ & $8(20.0 \%)$ \\
\hline Lactobacillus salivarius & $2(16.7 \%)$ & $4(33.3 \%)$ & $3(7.5 \%)$ \\
\hline Gemella haemolysans & 0 & $2(16.7 \%)$ & $4(10.0 \%)$ \\
\hline Acinetobacter junii & 0 & $1(8.3 \%)$ & 0 \\
\hline Staphylococcus capitis & 0 & $2(16.7 \%)$ & 0 \\
\hline Staphylococcus epidermidis & $4(33.3 \%)$ & 2 (16.7\%) & $8(20.0 \%)$ \\
\hline Staphylococcus warnerii & $3(25.0 \%)$ & $2(16.7 \%)$ & 0 \\
\hline Enterobacter cloacae & 0 & 0 & $6(15.0 \%)$ \\
\hline Citrobacter freundii & 0 & 0 & $2(5.0 \%)$ \\
\hline Escherichia coli & 0 & 0 & $1(2.5 \%)$ \\
\hline Candida albicans & $4(33.3 \%)$ & 0 & 0 \\
\hline
\end{tabular}




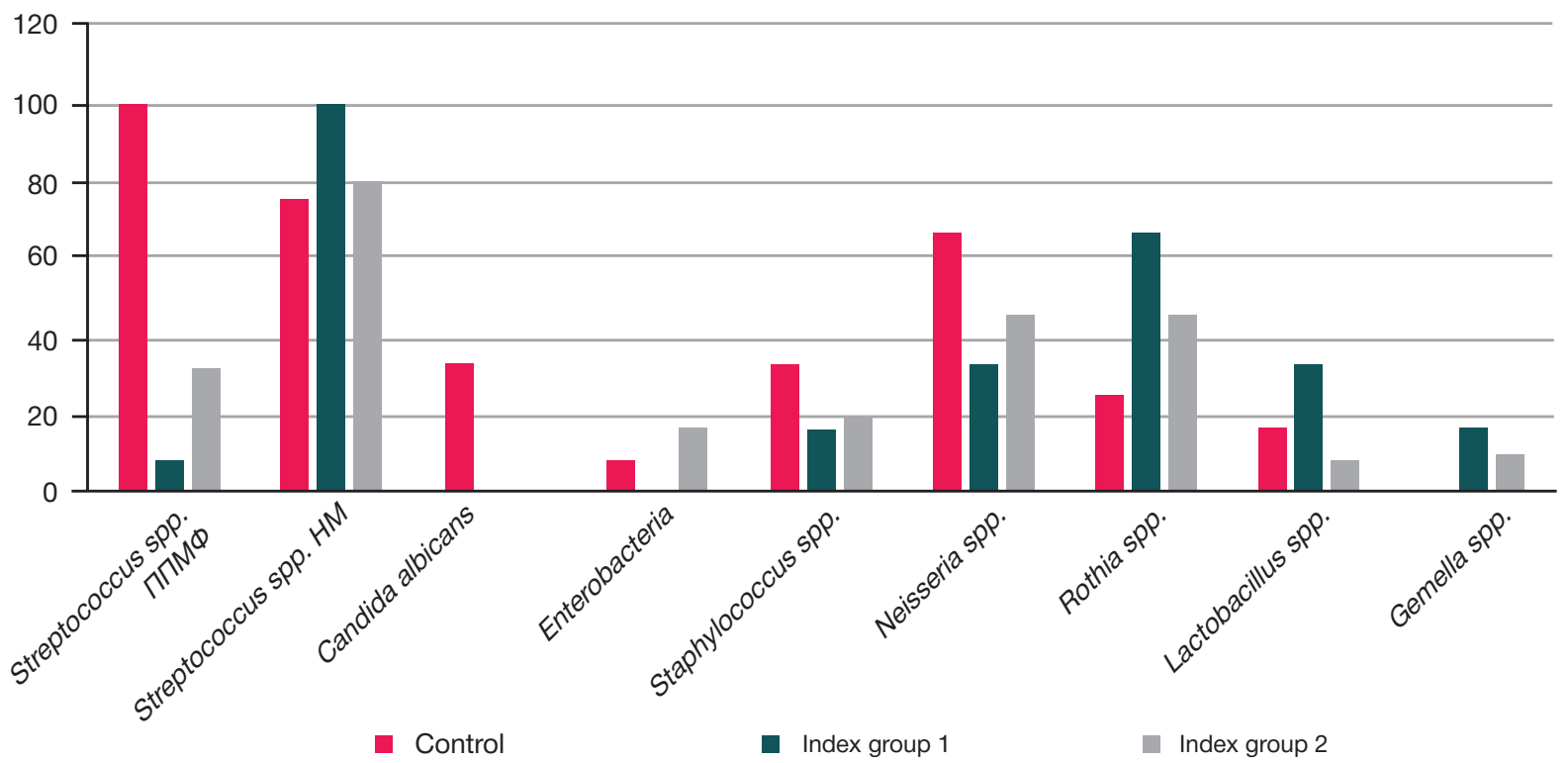

Fig. 1. Frequency of isolation of microorganisms from patients of different groups (\%). ППМФ — potentially pathogenic microflora, $\mathrm{HM}$ — normal microflora

predominance of normal microflora was observed, represented by streptococci, lactobacteria, representatives of the Rothia, Gemella genera. Opportunistic pathogenic Neisseria were less common than in the control group, and staphylococci were also less common.

In the 2nd index group, streptococci - representatives of normal microflora, Neisseria, as well as bacteria of the Rothia genus were the leaders by their incidence rate. However, it should be noted that this was the only group of patients from which enterobacteria were isolated.

In the control group, potentially pathogenic streptococci were found in $100 \%$ of the patients, which, of course, may have a negative effect in relation to the risk of complications in the early period after the implant is installed. Streptococci representatives of normal flora were isolated from more than $70 \%$ of patients. There was a decrease in the frequency of isolation of other normal microflora representatives, which were detected in less than $50 \%$ of the examined patients from the control group, with the exception of the Neisseria genus representatives. As described above, Candida fungi were isolated from one-third of the patients.

\section{DISCUSSION}

When analyzing the incidence degree of representatives of various microorganisms groups on the mucous membrane of the oral cavity around the neck of a dental implant, certain patterns were identified. In the control group, potentially pathogenic microorganisms prevailed characterized by increased adhesive activity, as well as the Candida genus fungi, which may be due to the specific location of the fixing elements in the basis of acrylic prostheses supported by cobalt-chrome abutments of commercial dental implants. The absence of complications in patients included in the study is due to the fact that, along with the potentially aggressive microflora, the normal microflora representatives were also rather common in the control group. In the index group 1, the optimal microbiological relationships were identified, both in terms of the qualitative composition of microflora and of the inoculation frequency of oral mucosa normal microbiota inhabitants. In this group, there was the lowest isolation frequency of potentially pathogenic streptococci, there was no candida and enterobacteria inoculation. The index group 2 was characterized by the maximum variety of both qualitative composition and isolation frequency of various microorganisms groups. Together with normal microflora, the potentially pathogenic streptococci as well as enterobacteria were identified, which, in our opinion, is the greatest threat in relation to the post-implantation complications formation [4, 7, 9-11].

It should be noted that almost all microorganisms having pathogenic potential were isolated under strict anaerobic conditions, which may be an indirect indicator of their active participation in the process of adaptation to the altered conditions on the mucous membranes around the neck of the dental implant. Significant changes in the qualitative composition of microflora and in the isolation frequency of various groups of microorganisms among patients in the control and index groups demonstrate the need for careful selection of the design of a dental implant, of an abutment, of a removable prosthetic appliance. In this case the main goals are minimization of the negative impact of a "foreign" object (dental implant) on intermicrobial interactions that can lead to the predominance of potentially pathogenic microorganisms with pronounced adhesive properties in the microbiocenosis, as well as the elimination of mucus membranes colonization with transient microflora with a high pathogenic potential, which can act as a trigger of the mucositis and peri-implantitis development. The negative impact of implants was confirmed by data obtained during the study: the predominance of microorganisms with high adhesive potential among the control group patients; a wide variety of transient microflora and enterobacteria in the index group 2.

The oral cavity microflora is a complex association of microorganisms, the qualitative and quantitative composition of which is influenced by various external and internal factors. Prosthetics using dental implants supported removable prosthetic appliances inevitably affects the mucous membranes microbiota. These changes can be conditionally "neutral" in relation to the prevailing groups of microorganisms, or they can lead to significant changes in the microflora composition, when representatives of normal microbiota are displaced by transient microorganisms, the number of which increases significantly on the mucous membranes of the oral cavity due to the use of removable prosthetic appliances.

It should be noted that the material of which dental implant abutments, fixing mechanisms and removable prosthetic appliances are constructed can influence the redistribution of 
the prevailing groups of microorganisms, increasing the number of bacteria and fungi with enhanced adhesive properties in the population of microorganisms on the surface of the dental implant abutment and on the oral mucosa, which is in direct contact with them. Such changes may remain subcompensated for a long time due to the adaptation mechanisms of bacterial survival in biofilms, but sooner or later they will lead to the accumulation of pathogenic potential of microorganisms, changes in the qualitative composition of microflora, colonizing the dental implant neck and the oral mucosa around it. Involvement in the process of initially potentially pathogenic streptococci, which include Streptococcus gordoni and a number of other microorganisms isolated from patients of the control group, will inevitably lead to an increase in the adhesive ability of other microorganisms, in particular, having proven pathogenic action, which is confirmed by the data described in the scientific literature $[4,7,9]$. Involvement in the process of colonization and change of the dominant microbial population of enterobacteria, staphylococci, fungi can be considered a serious risk factor for the development of post-implantation complications.

\section{CONCLUSIONS}

Implantologic and orthopedic types of treatment performed for patients of the 1st index group using collapsible dental implants supported removable prosthetic appliances with metal frame and fixing elements, telescopic crowns and clasps (patent of Russian Federation № 2593349) less changed the qualitative composition of the microflora of the oral mucosa around the dental implant neck compared to other methods of orthopedic treatment. In this group of patients, microflora was detected in a small amount, participating in the adhesion of paradontopathogenic microorganisms to oral mucosa, reducing the risk of periimplantitis.

The data obtained in the study indicate the influence of the type of prosthetic appliances and dental implants on the oral cavity microbiocenosis. Further research in this field will minimize the negative impact of orthopedic treatment on the qualitative composition of oral microflora, reduce the risk of complications, of the development of mucositis and periimplantitis.

\section{References}

1. Gvetadze RSh, Uzunjan NA, Lebedenko lyu, et al. Osseointegration of superelastic alloys of titanium and niobium. In the collection: Actual issues of dentistry Collection of scientific papers dedicated to the founder of the Department of Prosthetic Dentistry KSMU Professor Isaak M. Oksman, Kazan. 2018; 89-93.

2. Tlustenko VP, Tlustenko VS, Golovina ES, Koshelev VA. Effect of chronic localized periodontitis and dental periimplantitis on oral homeostasis. Journal of Scientific Articles Health and Education in the XXI Century. 2017; 19 (11): 102-6.

3. Utjuzh AS, Jumashev AV, Mihajlova MP. Prosthetic appliances made of titanium alloys with intolerance to traditional dentures. Doctor. 2016; (7): 62-64.

4. Gorobec SM, Romanenko IG, Dzherelej AA, et al. Risk factors for the development of inflammatory complications after the implantation. Tavrichesky Medical-Biological Journal. 2017; 20 (2): 208-14

5. Alkan EA, Tüter G, Parlar A, et al. Evaluation of peri-implant crevicular fluid prostaglandin levels in augmented extraction sockets by different biomaterials. Acta Odontol. Scand. 2016; 74 (7): 532-8.

6. Salivonchik MS, Kalivradzhiyan ES, Ryzhova IP. Results of

\section{Литература}

1. Гветадзе Р. Ш., Узунян Н. А., Лебеденко И. Ю. и др. Остеоинтеграция сверхупругих сплавов титана и ниобия. В сборнике: Актуальные вопросы стоматологии. Сборник научных трудов, посвященный основателю кафедры ортопедической стоматологии КГМУ профессору Исааку Михайловичу Оксману, Казань. 2018; 89-93.

2. Тлустенко В. П., Тлустенко В. С., Головина Е. С., Кошелев В. А. Влияние хронического локализованного пародонтита и дентального периимплантита на гомеостаз полости рта. Здоровье и образование в XXI веке. 2017; 19 (11): 102-6.

3. Утюж А. С., Юмашев А. В., Михайлова М. П. Ортопедические конструкции из сплавов титана при непереносимости традиционных зубных протезов. Врач. 2016; (7): 62-4.

4. Горобец С. М., Романенко И. Г., Джерелей А. А. и др. Факторь риска развития воспалительных осложнений дентальной имплантации. Таврический медико-биологический вестник. 2017; 20 (2): 208-14.

5. Alkan EA, Tüter G, Parlar A, et al. Evaluation of peri-implant crevicular fluid prostaglandin levels in augmented extraction sockets by different biomaterials. Acta Odontol. Scand. 2016; 74 (7): 532-8.

6. Саливончик М. С., Каливраджиян Э. С., Рыжова И. П. microscopy of basic polymers. Modern prosthetic dentistry. 2014; (22): 66-7.

7. Ryzhova IP, Prisnyj AA, Shinkarenko NN, Salivonchik MS. The state of the oral microflora under the influence of removable dentures. Intern journals applied and basic research. 2014; (2): 151-3.

8. Riega-Torres JC, Villarreal-Gonzalez AJ, Ceceñas-Falcon LÁ, Salas-Alanis JC. Sjögren's syndrome (SS), a review of the subject and saliva as a diagnostic method. Gac Med Mex. 2016; 152 (3): 371-80.

9. Habilov NL, Akbarov AN, Salimov OR, et al. Influence of removable laminar prostheses on the oral microbiocenosis. Medicus. 2016; 6 (12): 82-5.

10. Zekij AO, Zekij OE. Pathogenic microflora and the state of periimplantable tissues in patients with fixed prosthetic appliances with support on intraosseous implants using a silicone sealing matrix. Institute of Dentistry. 2018; (1): 37-9.

11. Shishkova YuS, Babikova MS, Orner lyu, et al. Features of the microbial spectrum of the oral fluid of persons using dental prosthetic appliances. Medical science and education of the Urals. 2017; 1 (89): 32-6.

Результаты микроскопии базисных полимеров. Современная ортопедическая стоматология. 2014; (22): 66-7.

7. Рыжова И. П., Присный А. А., Шинкаренко Н. Н., Саливончик М. С Состояние микрофлоры полости рта под влиянием съемных конструкций зубных протезов. Международный журнал прикладных и фундаментальных исследований. 2014; (2): 151-3.

8. Riega-Torres JC, Villarreal-Gonzalez AJ, Ceceñas-Falcon LÁ, Salas-Alanis JC. Sjögren's syndrome (SS), a review of the subject and saliva as a diagnostic method. Gac Med Mex. 2016; 152 (3): 371-80.

9. Хабилов Н. Л., Акбаров А. Н., Салимов О. Р. и др. Влияние съемных пластиночных протезов на микробиоценоз полости рта. Medicus. 2016; 6 (12): 82-5.

10. Зекий А. О., Зекий О. Е. Патогенная микрофлора и состояние периимплатационных тканей у пациентов с несъемными ортопедическими конструкциями с опорой на внутрикостные имплантаты при использовании герметизирующей силиконовой матрицы. Институт стоматологии. 2018; (1): 37-9.

11. Шишкова Ю. С., Бабикова М. С., Орнер И. Ю. и др. Особенности микробного спектра ротовой жидкости лиц, использующих стоматологические ортопедические конструкции. Медицинская наука и образование Урала. 2017; 1 (89): 32-6. 